\title{
The Effect of Dietary Supplementation of Cod Liver Oil on Ratio of Saturated and Unsaturated Fatty Acids in Giant Prawn (Macrobrachium rosenbergii) Meat
}

\author{
Lutfi Marzuki, Agustono* and Boedi Setya Rahardja \\ Department of Fish Health Management and Aquaculture, Faculty of Fisheries and Marine, Universitas Airlangga, Surabaya-60115, Indonesia \\ *Corresponding author`s Email: agustono@fpk.unair.ac.id; (D)RCiD: 0000-0001-8984-9323
}

\begin{abstract}
The existence of feed plays an important role in aquaculture activities. This is due to the dominant influence on fish feed growth. Feeding with the right nutritional components can produce healthy and high-quality fish products. One of the nutrients needed by fish is fatty acids. In fact, the provision of fatty acids, one of which is not in the meat, has an important influence. So, this study aims to determine the effect of adding cod liver oil to commercial feed on the ratio of saturated and unsaturated fatty acids to the meat of giant prawn. This research was conducted experimentally with a completely randomized design. The treatment is given a dose of cod liver oil 0\% (control), and treatments 1-4 use $3 \%$ dose addition to each treatment. On the other hand, in the data analysis stage, the researchers used ANOVA and continued with the Duncan's test. Based on the results, the study notes that the administration of cod liver oil in commercial feed does not affect the decreasing content of saturated fatty acids in giant prawn meat. On the other hand, the results also showed that the best ratio was found in treatment 4 at a dose of $12 \%$. Therefore, it is concluded that the provision of nutrients for feed related to fatty acids in the pole has not reduced the content of saturated fatty acids. As well as, the best ratio of saturated fatty acids and unsaturated fatty acids was 1.21:1 with cholesterol content of $88.34 \mathrm{mg} / \mathrm{dl}$ and this ration resulted by the greatest growth rate in present study.
\end{abstract}

Key words: Cod liver oil, Feed, Giant prawn, Saturated fatty acids

\section{INTRODUCTION}

Prawn in Indonesia is produced from the results of capture and cultivation, and Giant prawn cultivation has developed quite rapidly in the country. In this regard, it can be seen that the production of giant prawns in 2013 reached 3.171 tons (Indonesia report, 2013).

In overall, feed plays an important role in aquaculture activities because it serves a dominant role on fish growth in term of economic (Melianawati and Suwirya, 2010). Feeding with the right nutritional components can produce healthy and high-quality fish products. One of the nutrients needed by fish is fatty acids (Pangkey, 2011). Fatty acids are collected into two types, based on the degree of saturation; namely saturated and unsaturated fatty acids (Bragagnolo and Rodriguez-Amaya, 2001; Venugopal and Gopakumar, 2017; Allen et al., 2019). Saturated fatty acids do not affect oxidation and free radical formation as do unsaturated fatty acids. The dominant effect of saturated fatty acids is an increase in total cholesterol and LDL (Low-Density Lipoprotein) cholesterol (Sartika, 2008). On the other hand, it is known that giant prawns have 35\% saturated fatty acid levels and $139 \mathrm{mg} / 100 \mathrm{~g}$ cholesterol levels which was higher than sea shrimp (Bragagnolo and Rodriguez-Amaya, 2001; Venugopal and Gopakumar, 2017; Allen et al., 2019). The lack of unsaturated fatty acids will cause disruption in fish health including reduced fecundity, ability to form embryos and abnormal growth (Pangkey, 2011; de Carvalho and Caramujo, 2018).

Fat does indeed play an important role in increasing growth rate in aquacultures (Stoneham et al., 2018). Meanwhile, the percentage of saturated fatty acids can be reduced by adding essential fatty acids (Stoneham et al., 2018). Essential fatty acids include unsaturated fatty acids that have a double-bond that cannot be synthesized in the body of animal, so it needs to be intake through feed (Meliandasari et al., 2016). In fact, cod liver oil can be supplemented to increase the content of unsaturated fatty acids in diet (Turchini et al., 2009). It is known that unsaturated fatty acids are divided into 2 namely monounsaturated fatty acids (MUFA) and polyunsaturated fatty acids (PUFA). MUFA has one double carbon bond, which can occur in any position. PUFA has more than one double carbon bond, if the first double bond is found between the third and fourth carbon bonds it is called $\omega-3$ fatty acids. The first double bond between the sixth and seventh carbon atoms is called $\omega-6$ (Rustan and Drevon, 2005). Cod liver oil have a higher content of unsaturated fatty acids, and more than saturated-fatty acids (Das et al., 2007). So, present study was conducted with the aim to determine the effect of adding cod liver oil to commercial feed on the ratio of saturated and unsaturated fatty acids to giant prawn meat. 
This experiment was carried out at Prigi Brackish Aquaculture Plant, Trenggalek- East Java. Moreover, the research activities were carried out in June to July 2016.For the analysis of cod liver oil fatty acids and giant prawn meat, the activities were conducted on unit testing service at Faculty of Pharmacy, Universitas Airlangga, Surabaya.

The tools used include 20 pieces of aquarium measuring $35 \times 20 \times 25 \mathrm{~cm}^{3}$, aerators, aerated hoses, sipon (suction device), aeration stones, large plastic tubs, measuring cups, digital scales, thermometers, $\mathrm{pH}$ meters, DO meters, ammoniates test kits. On the other hand, the main ingredient used is giant prawns (Macrobrachium rosenbergii) weighing 9 grams. Other ingredients include cod liver oil baby's Docosahexaenoic Aacid (DHA) brand, fish commercial feed, and chlorine (National Chlorine Industries Co. Ltd, Japan).

This research was carried out using an experimental method that is an experiment in the field or testing in a laboratory (Arifin, 1998). The design was based on Completely Randomized Design (CRD) with a diversity of cod liver oil (Kusriningrum, 2008). This study used five treatments with four replications in each treatment. Determination of the number of repetitions in each treatment, then, the following formula is as follows:

$\mathrm{t}(\mathrm{n}-1) \geq 15$

Notes: $\mathrm{t}=$ the treatments tested; $\mathrm{n}=$ number of tests or groups.

The dosage of cod liver oil in each feed was $0 \%$ (control), 3\%, 6\%, 9\%, and 12\%. Determination of the dose is based on the results of study (Faradilah, 2015) that has been done at a dose of $9 \%$ of the amount of feed which shows the best decrease in cholesterol in vannamei shrimp meat with the addition of cod liver oil.

\section{Water quality}

Water quality parameters measured during the study were temperature, $\mathrm{pH}$, ammonia and Dissolved Oxygen (DO). The temperature was measured three times per day during the study, which was carried out at $06.00,12.00$, and 16.00 WIB (Indonesia's West Time Zone). Moreover, the measurement of $\mathrm{pH}$ and DO was done once a week while ammonia measurements are carried out twice during the study on the first day and the last day. This water quality measurement aims to monitor water quality conditions for giant prawns during maintenance. Temperature measurements were carried out three times a day, i.e. at 6:00 a.m. (Indonesia's West Time Zone), noon at $12.00 \mathrm{pm}$ and evening at 4pm using a thermometer. Observation of temperature in the range $28-29^{\circ} \mathrm{C}$. Measurement of the degree of acidity was done 3 times per day using a pH pen. From the observations, the acidity content is 6.5-7.5. This is in accordance with the statement where the optimal pH for giant prawn ranges from 6.0 to 8.5 (Erlangga, 2012). Measurement of marine oxygen (DO) was done once a week using a DO meter. DO observation results obtained $6-7 \mathrm{mg} / \mathrm{l}$. This is appropriate where giant prawns can live in dissolved oxygen content in water that can support shrimp life which is between $4-8 \mathrm{mg} / \mathrm{L}$ (Fatagar, 2014). Ammonia is measured once a week using test-kit ammonia. In this study, ammonia content of 0.02-0.75 mg/l was obtained. This is not appropriate where ammonia for giant prawn ranges from 0-0.3 (Arthur, 2004). This difference is influenced by the rest of the feed, where changes in ammonia can be caused by temperature, $\mathrm{pH}$ and feed (Kamarudin et al., 1994).

\section{RESULTS AND DISCUSSION}

\section{Saturated fatty acids}

The results showed that the value of giant prawn saturated fatty acid content ranged from $54.87 \%-59.13 \%$. Data on the average content of giant prawn saturated fatty acids are in table 1. Calculation of Analysis of Variants (ANOVA) showed no significant difference between each treatment $(\mathrm{P}>0.05)$. Duncan's test results showed that $\mathrm{P}_{0}$ was not significantly different with $\mathrm{P}_{1}, \mathrm{P}_{2}, \mathrm{P}_{3}$ and $\mathrm{P}_{4}(\mathrm{P}>0.05)$. From the in vitro analysis, the cod liver oil fatty acids obtained $8.9 \%$ content of dietary saturated fatty acids. When supplementing to commercial feed with a composition of $\mathrm{P}_{0}(0 \%)$ obtained analysis of saturated fatty acids of $11.85 \%, \mathrm{P}_{1}(3 \%)$ has a saturated fatty acid content of $10.496 \%, \mathrm{P}_{2}(6 \%)$ of saturated fatty acid content of $10.496 \%, \mathrm{P}_{3}(9 \%) 8.99 \%$ and $\mathrm{P}_{4}(12 \%) 8.97 \%$ data on saturated fatty acid content. A slight difference in the one factor; that supplement does not affect saturated fatty acids content (Table 1). This is in accordance with the feeding of fortified components of essential fatty acids which is an alternative method of regulating fat in livestock products (Legowo, 2004). The results presented in table 1 were not significantly different. It could be caused by the absorption of feed that it was not the same amount for each treatment.

\section{Unsaturated fatty acids}

The results showed the value of unsaturated fatty acid content of giant prawns ranged from $40.87 \%-45.14 \%$. Data on the average content of unsaturated fatty acids on giant prawn in table 2. The calculation of Analysis of Variants (ANOVA) showed that there is no significant difference $(\mathrm{P}>0.05)$ between each treatment. Duncan's distance test results show that $\mathrm{P}_{0}$ is not significantly different $(\mathrm{P}>0.05)$ with $\mathrm{P}_{1}, \mathrm{P}_{2}, \mathrm{P}_{3}$ and $\mathrm{P}_{4}$. The calculation of Analysis of Variant 
(ANOVA) results showed that there is no significant difference $(\mathrm{P}>0.05)$ for each treatment. This may be caused by the utilization of unsaturated fatty acids as energy and growth (possible mechanism). Tartrakoon et al. (2016) stated that the addition of unsaturated fatty acids to saturated fatty acids in feed will be accompanied by an increase in energy utilization. It was found out later that the process of utilizing unsaturated fatty acids as energy by means of fatty acids had undergone esterification that is forming esters with glycerol to triglycerides as energy reserves. Fatty acids are oxidized through beta oxidation and produce acetyl CoA which combines with acetyl CoA from the metabolism of carbohydrates and proteins, then, substitute to the citric acid cycle to produce energy (Lodish et al., 2000).

Table 1- Average saturated fatty acids contents of giant prawn

\begin{tabular}{lc}
\hline Treatments & $\begin{array}{c}\text { Saturated Fatty Acids Contents } \\
(\%) \pm \text { SD }\end{array}$ \\
\hline $\mathrm{P}_{0}$ & $59.13^{\mathrm{a}} \pm 10.2298$ \\
$\mathrm{P}_{1}$ & $58.41^{\mathrm{a}} \pm 5.4192$ \\
$\mathrm{P}_{2}$ & $57.71^{\mathrm{a}} \pm 6.0569$ \\
$\mathrm{P}_{3}$ & $55.81^{\mathrm{a}} \pm 5.0055$ \\
$\mathrm{P}_{4}$ & $54.87^{\mathrm{a}} \pm 4.3496$
\end{tabular}

Notes: $\mathrm{P}_{0}=$ commercial feed without the addition of cod liver oil, $\mathrm{P}_{1}=$ $100 \%$ commercial feed $+2 \%$ tapioca flour $+3 \%$ cod liver oil, $\mathrm{P}_{2}=$ $100 \%$ commercial feed $+2 \%$ tapioca flour $+6 \%$ cod liver oil, $\mathrm{P}_{3}=$ $100 \%$ commercial feed $+2 \%$ tapioca flour $+9 \%$ cod liver oil, $\mathrm{P}_{4}=$ $100 \%$ commercial feed $+2 \%$ tapioca flour $+12 \%$ cod liver oil. $\mathrm{SD}=$ Standard Deviation.

\section{Ratio of saturated and unsaturated fatty acids}

The data on the ratio of saturated and unsaturated fatty acids is obtained from the average content of saturated fatty acids divided by the average unsaturated fatty acid content of each treatment. The best ratio value is obtained from the lowest total cholesterol content in giant prawn meat and the best growth rate. Data on the ratio of saturated fatty acids and unsaturated fatty acids are presented in table 3. The best ratio of saturated fatty acids and unsaturated fatty acids can be seen from the value of cholesterol content in giant prawn meat and growth rate (Table 3). Cholesterol serves as a precursor of a number of compounds, such as sex hormones, adrenal cortex, bile acids and vitamin D. High cholesterol levels can cause heart attacks and strokes. According to Rosenthal (2000), the optimal content of cholesterol is below $100 \mathrm{mg} / \mathrm{dl}$. The best growth rate is obtained from the value of the growth rate during maintenance.

Table 3. Ratio of saturated fatty acids and unsaturated fatty acids, cholesterol and growth Rates

\begin{tabular}{lccc}
\hline Treatments & $\begin{array}{c}\text { Saturated } \\
\text { Fatty Acids }\end{array}$ & $\begin{array}{c}\text { Unsaturated } \\
\text { Fatty Acids }\end{array}$ & Ratio \\
\hline $\mathrm{P}_{0}$ & 59.13 & 40.87 & $1.45: 1$ \\
$\mathrm{P}_{1}$ & 58.41 & 41.59 & $1.41: 1$ \\
$\mathrm{P}_{2}$ & 57.71 & 42.29 & $1.36: 1$ \\
$\mathrm{P}_{3}$ & 55.81 & 44.18 & $1.26: 1$ \\
$\mathrm{P}_{4}$ & 54.81 & 45.14 & $1.21: 1$ \\
\hline
\end{tabular}

Table 2. Average unsaturated fatty acid contents

\begin{tabular}{lc}
\hline Treatments & $\begin{array}{c}\text { Unsaturated Fatty Acids Contents } \\
(\%) \pm \text { SD }\end{array}$ \\
\hline $\mathrm{P}_{0}$ & $40.87^{\mathrm{a}} \pm 10.2255$ \\
$\mathrm{P}_{1}$ & $41.59^{\mathrm{a}} \pm 5.4146$ \\
$\mathrm{P}_{2}$ & $42.29^{\mathrm{a}} \pm 6.0543$ \\
$\mathrm{P}_{3}$ & $44.18^{\mathrm{a}} \pm 4.9998$ \\
$\mathrm{P}_{4}$ & $45.14^{\mathrm{a}} \pm 4.3820$ \\
\hline Notes: $\mathrm{P}_{0}=$ commercial feed without the addition of cod liver oil, $\mathrm{P}_{1}=$ \\
$100 \%$ commercial feed $+2 \%$ tapioca flour $+3 \%$ cod liver oil, $\mathrm{P}_{2}=$ \\
$100 \%$ commercial feed $+2 \%$ tapioca flour $+6 \%$ cod liver oil, $\mathrm{P}_{3}=$ \\
$100 \%$ commercial feed $+2 \%$ tapioca flour $+9 \%$ cod liver oil, $\mathrm{P}_{4}=$ \\
$100 \%$ commercial feed $+2 \%$ tapioca flour $+12 \%$ cod liver oil. $\mathrm{SD}=$ \\
Standard Deviation.
\end{tabular}

From these data (Table 4) the addition of cod liver oil as many as $12 \%$ obtained a ratio of 1.21:1 which is a suitable ratio in terms of total cholesterol content. It is known that giant prawns that are fed commonly with the addition of $12 \%$ cod liver oil to meat, have a total cholesterol of $88.31 \mathrm{mg} / \mathrm{dl}$, while giant prawns that are fed the same common feed but without the addition of cod liver oil cholesterol is $385.03 \mathrm{mg} / \mathrm{dl}$. The total cholesterol content can be seen in table 4 . Through table 4 , it is seems that the smaller the ratio, will resulted with better the cholesterol value. This is adjusted to the addition of unsaturated fatty acids (UFA) that can reduce total cholesterol because it is neutral against LDL (does not decrease or increase), but can increase HDL lipoprotein (Mora and Selpas, 2013). In accordance with the value of the growth rate which was the best ratio obtained 1.21:1, the supplementation of cod liver oil by $12 \%$ is the best rate of growth, while feed whose composition of cod liver oil is reduced has decreased growth rate (Sobirin, 2016).

The small ratio of saturated fatty acids (SFA) and unsaturated fatty acids (UFA), the better the rate of growth, because saturated fatty acids are inversely proportional to UFA. This is in accordance with conditions where the ratio of saturated and UFA of 33.32:66.68 has a growth rate of $3.53 \mathrm{gr} /$ day (Das et al., 2007). Lack of UFA will cause growth disturbance (Pangkey, 2011). As a matter of fact, consuming foods that contain lots of palmitate stearate can cause heart attacks due to clogged arteries. Consequently, the distribution of nutrients is inhibited and affects growth. This is 
according to the fact that nutrition is very important so that fish have the ability to survive from disease and grow as desired (Pangkey, 2011).

\section{CONCLUSION}

Based on results, it can be concluded that, the supplementation of cod liver oil in commercial feed does not affect the ratio of the saturated and unsaturated fatty acids in giant prawn meat. The optimum ratio of saturated fatty acids to unsaturated fatty acids is $1.21: 1$ with cholesterol content of $88.34 \mathrm{mg} / \mathrm{dl}$.

\section{REFERENCES}

Allen KM, Habte-Tsion H, and Thompson KR (2019). Freshwater microalgae (Schizochytrium sp.) as a substitute to fish oil for shrimp feed. Scientific Report, 9: 6178. DOI: https://doi.org/10.1038/s41598-019-41020-8

Arifin EZ (1998). Dasar-dasar penulisan karangan ilmiah, Jakarta: PT Gramedia Widiasarana Indonesia (Grasindo). ISI Press, Surakarta. Available at: http://repository.isi-ska.ac.id/1395/3/Dasar-Dasar\%20Penulisan\%20Ilmiah.pdf

Arthur JR (2004). 'Pathogen and Ecological Risk Analysis for the Introduction of Giant River Prawn, Macrobrachium Rosenbergii, from Fiji to Cook Islands', A consultancy report prepared for the Secretariat of the Pacific Community, Noumea Cedex, New Caledonia, under Contract Pro, 7(54): 8. Available at: file:///C:/Users/ok/Downloads/600905cbffbec3ce7902423a2633f8bf.pdf

Bragagnolo N, and Rodriguez-Amaya DB (2001). Total lipid, cholesterol, and fatty acids of farmed freshwater prawn (Macrobrachium rosenbergii) and wild marine shrimp (Penaeus brasiliensis, Penaeus schimitti, Xiphopenaeus kroyeri). Journal of Food Composition and Analysis, Pp. 359-369. DOI: https://doi.org/10.1006/jfca.2000.0981

Das SK, Tiwari VK, Venkateshwarlu G, Reddy AK, Parhi J, Sharma P, and Chettri JK (2007). Growth, survival and fatty acid composition of Macrobrachium rosenbergii (de Man, 1879) post larvae fed HUFA-enriched Moina micrura. Aquaculture, 269(14): 464-475. DOI: https://doi.org/10.1016/j.aquaculture.2007.04.069

de Carvalho C, and Caramujo MJ (2018). The Various Roles of Fatty Acids. Molecules (Basel, Switzerland), 23(10): 2583. DOI: https://doi.org/10.3390/molecules23102583

Erlangga E (2012). Meraup Untung dari Budi Daya Udang Galah pada Kolam Air Tawar', Pustaka Agro Mandiri. Tangerang Selatan. hal, pp. 6-49. Available at: http://perpustakaan.kkp.go.id/union/index.php?p=show_detail\&id=40370

Faradilah F (2015). 'Pengaruh Cod Liver Oil pada Pakan Komersial terhadap Kolesterol, low density lipoprotein (LDL), high density lipoprotein (HDL) Daging Udang Vanamei', Skripsi. Budidaya Perairan. Fakultas Perikanan dan Kelautan. Universitas Airlangga, p. 70. Available at: http://repository.unair.ac.id/57134/

Fatagar SH (2014). Jumlah Konsumsi Pakan Udang Galah (Macrobrachium rosenbergii) yang Diberi Pakan Atraktan Berbeda', Skripsi. Budidaya Perairan. Fakultas Perikanan dan Ilmu Kelauta. Institut Pertanian Bogor. Bogor, p. 3. Availble at: https://adoc.pub/jumlah-konsumsi-pakan-udang-galah-macrobrachium-rosenbergii-.html

Indonesia Report (2013). Sentra Produksi Budidaya Udang Galah di Indonesia', Statistik Perikanan Budidaya Indonesia. Indonesia. Pp. 1-35. Available at: http://kkp.go.id/an-component/media/upload-gambarpendukung/kkp/LAPORAN/Laporan\%20Tahunan\%20KKP\%202017\%20(FINAL\%20OK).pdf

Kamarudin MS, Jones A, Vay L, and Zainal Abidin A (1994). Ontogenetic change in digestive enzyme activity during larval development of Macrobrachium rosenbergii, Aquaculture, 123(3-4): 323-333. DOI: https://doi.org/10.1016/0044$\underline{8486(94) 90068-X}$

Kusriningrum RS (2008). Perancangan percobaan, Universitas Airlangga. Surabaya. hal, p.82.

Legowo AM (2004). Pengembangan produk ternak rendah lemak dan tinggi asam lemak tidak jenuh', Journal of The Indonesian Tropical Animal Agriculture, 29(4): 225-233. Available at: http://www.jppt.undip.ac.id/pdf/29(4)2004p225-233.pdf

Lodish H, Berk A, and Zipursky SL (2000). Molecular cell biology. 4th edition. New York: W. H. Freeman, Section 16.1, oxidation of glucose and fatty acids to CO2. Available at: https://www.ncbi.nlm.nih.gov/books/NBK21624/

Melianawati R, and Suwirya K (2010). Optimasi tingkat pemberian pakan terhadap benih kerapu sunu (Plectropomus leopardus), in Prosiding Forum Inovasi Teknologi Akuakultur, pp. 659-665. Available at: https://adoc.pub/optimasi-tingkat-pemberian-pakanterhadap-benih-kerapu-sunu-.html

Meliandasari D, Dwiloka B, and Suprijatna E (2016). Optimasi daun kayambang (Salvinia molesta) untuk penurunan kolesterol daging dan peningkatan kualitas asam lemak esensial. Jurnal Aplikasi Teknologi Pangan, 4(1): 22-27. Available at: http://journal.ift.or.id/files/Optimasi\%20Daun\%20Kayambang\%20(Salvinia\%20molesta)\%20untuk\%20Penurunan\%20Kolestero 1\%20Daging\%20dan\%20Peningkatan\%20Kualitas\%20Asam\%20Lemak\%20Esensial.pdf

Mora E, and Selpas N (2013). Isolasi dan Karakterisasi Asam Oleat dari Kulit Buah Kelapa Sawit (Elais guinensis Jacq.). Penelitian Farmasi Indonesia, 1(2): 47-51. Availble at: https://pfi.ejournal.unri.ac.id/index.php/FPFI/article/viewFile/1245/1236

Pangkey H (2011). Kebutuhan asam lemak esensial pada ikan laut', Jurnal Perikanan dan Kelautan Tropis, 7(2): 93-102. DOI: https://dx.doi.org/10.35800/jpkt.7.2.2011.185

Rosenthal RL (2000). Effectiveness of altering serum cholesterol levels without drugs. Proceedings (Baylor University, Medical Center), 13(4): 351-355. DOI: https://doi.org/10.1080/08998280.2000.11927704

Rustan AC, and Drevon CA (2005). Fatty Acids: Structures and Properties. In eLS Edition, Wiley, Uk, Pp. 1-8. DOI: https://doi.org/10.1038/npg.els.0003894

Sartika RAD (2008). Pengaruh asam lemak jenuh, tidak jenuh dan asam lemak trans terhadap kesehatan. Kesmas: National Public Health Journal, 2(4): 154-160. DOI: http://dx.doi.org/10.21109/kesmas.v2i4.258 
Sobirin M (2016). Pengaruh penambahan cod liver oil (CLO) pada pakan komersial terhadap laju pertumbuhan, rasio konversi pakan dan efisiensi pakan udang galah (Macrobrachium rosenbergii)'. Universitas Airlangga. Available at: http://repository.unair.ac.id/57129/

Stoneham TR, Kuhn DD, Taylor DP, Neilson AP, Smith SA, Gatlin DM, Chu H, and O'Keefe SF (2018). Production of omega-3 enriched tilapia through the dietary use of algae meal or fish oil: Improved nutrient value of fillet and offal. PloS One, 13(4): e0194241. DOI: https://doi.org/10.1371/journal.pone.0194241

Tartrakoon W, Tartrakoon T, ad Kitsupee N (2016). Effects of the ratio of unsaturated fatty acid to saturated fatty acid on the growth performance, carcass and meat quality of finishing pigs. Animal nutrition (Zhongguo xu mu shou yi xue hui), 2: 79-85. DOI: https://doi.org/10.1016/j.aninu.2016.03.004

Turchini GM, Torstensen BE, and Ng WK (2009). Fish oil replacement in finfish nutrition. Reviews in Aquaculture, 1: 10-57. DOI: https://www.doi.org/10.1111/j.1753-5131.2008.01001.x

Venugopal V, and Gopakumar K (2017). Shellfish: Nutritive Value, Health Benefits, and Consumer Safety. Comprehensive Reviews

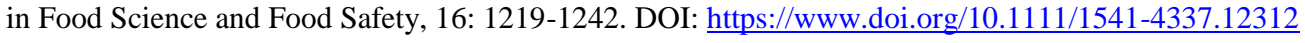

